\title{
ANALYSIS OF MODERN VIEWS ON THE ETIOLOGY OF DYSGRAPHIA
}

\author{
Larysa Zhuravlova \\ Department of Social work, Social Pedagogics and Preschool Education \\ Melitopol Bohdan Khmelnitsky State Pedagogical \\ 20 Hetmanska str., Melitopol, Zaporizhzhia region, Ukraine, 72300 \\ zuravlovalarisa@gmail.com
}

\begin{abstract}
The article considers the problem of dysgraphia as one of types of written speech disorders, studied by speech therapists, psychologists, neurophysiologists and neuropsychologists of different countries for more than hundred years, but still one of most difficult and urgent till now. It is explained, that writing disorders are denoted in the special literature by the term "dysgraphia". It is noted, that the term "dyslexia" is actively used by foreign scientists. In several countries (USA, UK) writing disorders are considered as ones, accompanied by dyslexia. Using the term «dyslexia», foreign scientists understand it as difficulties in mastering sign activity, first of all reading and writing. It is accented, that in works of German scientists difficulties in reading, writing and mathematics are denoted by the term «Lese-Rechtschreibshwache». French scientists interpret mistakes in letter denotation of the sound composition of a word in writing and orthographical mistakes as «Dysorthographie», «D’orthographie». It is accented, that the question of the dysgraphia essence still insufficiently studied for today, despite its complex studying in different aspects: clinical, pedagogical, psychophysiologic, neurophysiologic, psychogenetic, psychological-pedagogical, psycholinguistic, neuropsychological. At that certain questions, connected with writing disorders, are interpreted ambiguously, sometimes contradictorily. One of such questions is causes of dysgraphia appearance. It is noted, that three different conceptions are separated in studies, devoted to the dysgraphia etiology: functional, organic and genetic determination; the influence of unfavorable factors in prenatal, natal and postnatal periods; importance of social causes of dysgraphia. It is explained, that studies of dysgraphia in the psychogenetic aspect indicate that disorders of written speech often have the hereditary character. From the clinical point of view, written speech disorders in children are considered as results of the minimal cerebral dysfunction. Scientists' views on this problem in the neurophysiologic aspect are considered. It is noted, that difficulties in writing skills formation are the result of the whole complex of etiologic factors. Each of the mentioned factors, moreover their combination, can become a cause of difficulties in writing skills formation.
\end{abstract}

Keywords: writing, dysgraphia, dysgraphia causes.

\section{Introduction}

The problem of written speech disorders, especially, dysgraphia is studied by speech therapists, psychologists, neurophysiologists and neuropsychologists of different countries for more than hundred years, but still one of most difficult and urgent till now. Scientists consider dysgraphia as a partial disorder of the writing process, manifested by stable and frequent specific mistakes $[1,2]$. Dysgraphia it is not only pedagogical, but also medical problem [3]. According to the international classification of diseases (ICD-10), medical statistics doesn't separate it as a special point: this speech pathology is considered as specific disorders of school skills formation F81. These disorders are called specific ones because of the necessity to accent the fact that they are not connected with intellectual development disorders or hard defects of analyzers, have their own pathological mechanism and are characterized by several general positions: presence of signs of the cerebral dysfunction; disharmony of ripening of separate cognitive functions; stable difficulties in acquiring certain school and socially important skills (reading, writing, mathematics, language and speech skills and so on); dissociation between potential cognitive abilities and real school achievements.

\section{Analysis of literary data and statement of the problem}

The logopedic and medical literature denotes writing disorders by the term "dysgraphis". In several countries (USA, UK) writing disorders are considered as ones, accompanied by dyslexia. Using the term «dyslexia», scientists understand it as difficulties in mastering sign activity, first of all reading and writing $[4,5]$. At such speech pathology, the ability to impressive and expressive speech, including the alphabet, ciphers and music symbols' systems, is disturbed [4]. Symptoms can 
be manifested as isolated or complex disorders of reading, writing, orthography, written speech, counting and music notation [6]. In works of German scientists difficulties in reading, writing and mathematics are denoted by the term «Lese-Rechtschreibshwache» [7]. French scientists interpret mistakes in letter denotation of the sound composition of a word in writing and orthographical mistakes as «Dysorthographie», «D'orthographie» $[8,9]$.

The question of the dysgraphia essence still insufficiently studied for today, despite its complex studying in different aspects: clinical, pedagogical, psychophysiological, neurophysiologic, psychogenetic, psychological-pedagogical, psycholinguistic, neuropsychological. At that certain questions, connected with writing disorders, are interpreted ambiguously, sometimes contradictorily. One of such questions is causes of dysgraphia appearance.

\section{Aim of research}

The article is directed on the scientific-theoretical analysis of the following aspects:

1. The determination of the content and interconnection between approaches to understanding the notion "dysgraphia".

2. The combination of existent point of views as to causes of writing disorders.

\section{Research Methodology}

The methodological base of the research, which results are presented in the article, is a set of methods of scientific knowledge, general methods, methods and principles, including, analysis, synthesis, generalization, comparison of data of the special scientific-methodical literature for elucidating the psychogenetic, neurophysiologic, clinical, psychological-pedagogical aspects of studies, devoted to the dysgraphia etiology. The theoretical base of the study is the main theses about written speech as a complicated conscious form of speech activity, about higher psychic functions as complicated functional systems, about integrative cerebral activity in the process of psychic activity. Scientific works of native and foreign scientists are used in the article.

\section{Results of the research. In the epistemological sense, the economic security in an enterprise can have dual nature}

The different conceptions are separated in studies, devoted to the dysgraphia etiology: functional, organic and genetic determination; the influence of unfavorable factors in prenatal, natal and postnatal periods; importance of social causes of dysgraphia.

Depending on approaches to determination of preconditions and writing structure, scientists express a bit different views on causes and mechanisms of writing disorders.

Difficulties in mastering written speech can appear as a result of the system underdevelopment of oral speech, connected with non-formation of oral generalizations: phonetic, morphologic, syntactic ones [10, 11]. The oral and written speech forms are considered as different stages of language consciousness. Disturbances of conditions of mastering reading and writing (ability to separate the sound side of a word from the sense one; ability to analyze the sound composition of a word, distinctly pronouncing it in all parts; certain language generalizations, collected at comparison of words and their forms with each other; mastering of a sufficient vocabulary; realization of a certain logic elaboration of the morphological composition of the existent vocabulary; the ability to separate the significant parts of a word) result in difficulties of writing skills formation and appearance of dysgraphia [10]. But there is not always a direct correlation between defects of oral speech and writing [12]. In several cases dyslexia and dysgraphia can be traced in children, even after correction of defects in oral speech. It is connected with the higher stability of old visual stereotypes of a sound, presented as a letter [13].

The problem of written speech disorders, especially, dysgraphia is studied in different aspects. Studies of dysgraphia in the psychogenetic aspect indicate that disorders of written speech often have the hereditary character $[14,15]$.

There is transmitted the qualitative immaturity of separate cerebral structures that participate in written speech organization [16]. It is proved, that heredity conditions not only abilities to mastering written speech, but also the functional specialization of cerebral hemispheres [17]. The 
importance of genetic factors in the dysgraphia etiology is testified by works of foreign scientists and appearance of two psychogenetic research methods - genealogical and twin ones.

The results of twin studies prove the role of genetic factors in dysgraphia appearance [18], but genetic models of transmission ways of the written speech pathology are not determined till now. The most spread one is the autosomic-dominant heredity type. Using the genealogical method, there was conducted the study in families with the high prevalence of dyslexia. Based on it, the autosomic-dominant heredity type with its sexual modification of the expression degree was supposed [19]. A hypothesis about the genetic transmission of writing and reading disorders was proved by later studies of twins [5]. The most heredity indices were obtained for writing disorders and insufficiency of phonemic perception. As a result of molecular studies of the hereditary inclination to writing and reading disorders [20], there was separated a specific zone (gene) on the 15-th chromosome that, according to scientists, can be a marker of dyslexia. Studies in this direction proved disorders of not one, but several genes. There were also found other genes, which modification can cause dysgraphia and dyslexia. Scientists note, that certain types of dyslexia are inherited in different families [20, 21]. Heredity marks are rather low for spelling, but rather higher for orthography and ability to distinguish phonemes [22]. At that the phonologic disability it is a dyslexia component, most genetically independent from the intellect.

From the clinical point of view, written speech disorders in children are considered as results of the minimal cerebral dysfunction (MCD), caused by early local injuries of the brain [23, 24]. At the minimal cerebral dysfunction children demonstrate the delay in rates of the development of cerebral functional systems that provide complicated integrative functions. At that the general intellectual level of this category of children is within norm, but essential difficulties in school studying and social adaptation are observed in them. The minimal cerebral dysfunction can be manifested in the age immaturity of separate higher psychic functions and their disharmonic development, and also as formation disorders of reading, writing or counting skills. Most often these disorders are combined with each other, and also with oral speech disorders, revealed in schoolchildren at the moment of examination or in anamnesis.

Children with the minimal cerebral dysfunction have the reliably higher probability of dysgrapia comparing with their healthy coeval [25].

From the neurophysiologic point of view, the one of causes of the speech development at reading and writing disorders is non-formation of cortical rhythmogenesis that reflects the essential immaturity of the cortical electric activity [26, 27]. But disorders of bioelectric activity in children with dyslexia are unstable and determined, most of all, at functional loads that testifies to the mainly functional inferiority of cerebral systems as a result of delaying their ripening [3].

Children with reading and writing disorders demonstrated inconsistency to age normatives of functional maturity of the frontal-thalamic associative system that conditions attention disorders and low ability to the arbitrary regulation of activity [28]. As a result of the dysfunction of a series of speech cerebral structures, children have the decreased ability to sounds perception that influences identification of language symbols by acoustic signs. According to the results of electroencephalogram (EEG) children demonstrate evident of decreasing threshold of convulsive readiness, at that local changes prevail in back sections of the left hemisphere (occipital, sincipital, temporal-sincipital, occipital and back temporal zones) [28].

From the psychophysiological point of view, dysgraphia can be conditioned by disorders of analyzers' activity (speech-auditory and speech-motor ones) that the development of phonemic perception depends on [29]. The writing process depends on the level of formation of the speech-motor, auditory, optic, motor analyzers that provide the proper level of the development of articulation, phonemic perception and ideas, auditory and vision functions and operations, fine motility.

Among the most essential causes that are the base of written speech disorders of the diverse genesis are [30]:

1) disorders of receptors, especially of vision and hearing;

2) unfavorable environmental conditions;

3) intellectual disorders (oligophrenia) and as a result - disturbance of the ability to analysis and synthesis, necessary for mastering reading and writing; 
4) injuries of the brain, consequences of traumas or nidal lesions after mastering speech that essentially complicate mastering of reading and writing;

5) motility disorders, for example, consequences of child cerebral paralysis, manifested in upper extremities motility disorders;

6) negative attitude to school and teachers, accompanied by difficulties in mastering reading and writing;

7) general long diseases. These authors noted that a distinctly localized cerebral injury was inevitably assumed as a reliable cause of writing and reading disorders up to the certain moment of the science development. But then these written speech disorders became to be considered as a result of an innate defect or development anomaly.

Dysgraphia appearance in children is most fully explained as a polyfactor model that considers difficulties in mastering writing as a result of three groups of phenomena: biological inadequacy of cerebral systems, included in the system of written speech, functional inadequacy, appeared on this base and environmental conditions that make excessive requirements to immature persons or ones, who remain behind in the development of physical functions. Biological inadequacy of the functional system can have both hereditary and encephalopathic character [3]. Constitutional preconditions include parents' or relatives' psychic diseases and written speech disorders, individual features of the functional specialization of cerebral hemispheres. Scientists separate lateralization process - functional asymmetry in functioning of pair sensor-motor organs, conditioned by insufficient differentiation of cerebral hemispheres' functions as one of causes of dysgraphia [19,31]. The influence of badly developed lateralization on written speech is indirect, because the key importance belongs to non-formation of space ideas, connected with laterality state $[2,18]$.

Scientists mainly think that dysgraphia most often has the hereditary-encepalopathic origin: that is complicated heredity combines with the influence of exogenous factors in prenatal, natal and postnatal periods $[3,32]$. At that the more important role in the etiology of written speech disorders belongs to rather later factors. As a result of such harmful influence there is a delay in formation of certain complicated functional systems that ripe lately and are important for mastering written speech $[2,18]$.

Characterizing encephalopathic disorders, four types of nervous system development disorders are separated: hypoxic, toxic, mechanical, infectious [3]. At encepalopathic variants of the dysgraphia etiology prevail manifestations of asynchrony and partial underdevelopment of psychic functions. Such kind of dysontogenesis influences formation of successive functions, vision-motor coordination, special orientation, attention, memory, speech skills and series of other functions. Children with specific writing disorders have expressed unevenness of the development of separate sensor-motor and intellectual functions. At such dysontogenesis, difficulties at studying appear, according to the author, not only because of immaturity of certain functions, but because of disharmony in their ripening as a system construction. So, along with development asynchrony, two types of dysonthogenesis: delayed development and partial psychic underdevelopment - participate in pathogenesis of written speech disorders.

There are data that hereditary complication doesn't always result in written speech disorders, or they have a relatively favorable prognosis. In overwhelming majority of cases 2-3 exogenous harms occur in the anamnesis of children with writing and reading disorders. They result in injuring cerebral structures just most often. At that injuries at the early stages of intrauterine development more often cause anomalies of the development of subcortical structures, and peri- and postnatal anomalies hurt higher, cortical cerebral sections more [3].

Functional causes that condition dysgraphia can be connected with the influence of internal (for example, long somatic diseases) and external (incorrect spelling environment, deficit of speech contacts, bilingualism in a family, insufficient attention to the speech development of a child by adults) factors that delay formation of psychic functions that participate in the writing process $[1,32]$. Several researchers relate an incorrectly chosen way of teaching writing to this group of factors [11]. 
There are separated unfavorable social and environmental factors that condition dysgraphia:

- Inconsistency of teaching methods and rates to individual features of a child;

- Inconsistency of time of the beginning of teaching reading and writing to the real maturity of a child;

- Inconsistency of the volume of requirements level as to reading and writing to child's possibilities [3].

Reading and writing disorders can appear at bilingualism. Dyslexia and dysgraphia under conditions of bilingualism are influenced by both psychological difficulties and ones of speech formation and difficulties of studying [1]. The expressive speech, developed under conditions of bilingualism, is characterized by diverse disorders: spelling, non-formation of lexical-grammar structure and understanding of speech. Mastering of language generalizations is complicated at bilingualism. As far as each language is characterized by own phonetic system, certain regularities of the grammar order, in the process of mastering oral speech regularities of one language can contradict to ones of another one, still badly mastered [1]. So, oral speech formation disorders, difficulties of mastering language generalizations at bilingualism can, first of all, condition dyslexia and dysgraphia. The psychological conflict and affective disorders in such children can increase reading and writing disorders manifestations at the same time [1]. The scientists [33, 34] think that phonemic adaptation is an important factor that causes reading and writing disorders at bilingualism. Specific language features can negatively influence writing formation in a young schoolchild, in which result a child makes specific mistakes, typical for dysgraphia, in writing works. Studies of bilingual children demonstrated that ones with dyslexia have same difficulties in reading and writing in both their languages [33]. This deficit is usually phonologic, and it can in further prevent formation of writing skills [34]. Similarly to languages with the alphabet system, phonologic adaptation is also important for teaching reading in languages with the hieroglyphic system, for example, Chinese [6]. Chinese children with dyslexia have the lower level of phonetic adaptation and difficulties in studying the other language, English [6]. They demonstrated the decrease of activation in temporal-sincipital brain zone at making tasks in English [35].

Difficulties in writing skills formation can be connected with intensification of study, connected with weakening of psychic and physical child health [36, 37]. Among studied children (73\%), admitted in I class of a secondary school, there were diagnosed non-formation of the emotional-volitional sphere, dynamic organization of subject actions, auditory-speech memory, visual-image and verbal-logic thinking forms [37]. Non-formation of higher psychic functions in these children was manifested in delaying formation of the internal structure of the psychic process. From its side, unevenness of the development of higher psychic functions can cause weaker links of any functional system that decelerate further development of a child and, correspondingly, prevent its successful studying $[3,36]$.

\section{Discussion}

It must be noted, that biological factors are very important in first years of a child life, whereas the role of socio-psychological ones grows till school studying. Family education has a special importance, because extra-family and intra-family influences mediate remote ones of previous injuries of the nervous system in the process of intrauterine development or at childbirth on the intellectual development of a child.

Writing it is an extremely complicated integrative skill, which formation provides certain phases, connected with involvement of practically all sensor systems and brain structures in activity $[38,39]$. The multimodal character of writing determines the diversity of causes that are the base of its formation and gives reasons to think that difficulties in studying these skills of young pupils have the complex character and complicate the correcting-pedagogical work.

At studying the speech development of a child with dysgraphia, it is necessary to take into account the limiting factor of higher psychic functions (ratio between insufficiency of verbal and non-verbal higher psychic functions), the state of the psychic level of writing organization (possible psychological mechanisms of its disturbance) and probability of deviations in writing organization as a type of activity. The break of interactions between functional components of written speech 
and also insufficiency of main elements of writing activity in several cases can be an independent cause of writing disorders, in other ones - to intensify dysgraphia symptoms in the aspect of language disorders. The problem of dysgraphia must be solved complexly and systematically, taking into account the interconnection and determination of the whole psychic sphere and all forms of activity, because of its complexity and multi-aspect character.

But the efficiency of the logopedic work for correcting dysgraphia is not enough high for today and doesn't correspond to modern requirements of the speech competence of young schoolchildren. The presence of dysgraphia prevents children's mastering of written speech as a specific speech form, original means of communication and generalization of the experience, which comprehension is connected with qualitative changes of intellectual, emotional, volitional and other spheres of pupils' personality. The problem of the improvement of the organization and content of the timely complex help to younger schoolchildren with dysgraphia in the comprehensive educational space has a first-turn importance for raising effectiveness of the learning-upbringing process and their adaptation in the environment of healthy coevals.

\section{Conclusions} literature:

So, we make the following conclusions, based on the analysis of the special scientific

1. There is no single understanding of the notion "dysgraphia" till now that testifies to the complexity of this disorder and multi-aspect character of its study.

2. Dysgraphia it is a specific disorder of speech activity in children and at the same time disturbance of functioning of one of the most important school skills - writing. It explains the special interest of scientists to studying dysgraphia and conditions the necessity of more detail research of the problem under modern conditions.

3. Difficulties, appeared at formation of writing skills, are the result of the whole complex of etiological factors. Each one of the mentioned factors, moreover, their combination, can be the cause of difficulties in writing skills formation.

4. The study of interactions of socio-psychological and biological factors and their influence on writing disorders in children needs a further detail interdisciplinary research.

\section{References}

[1] Lalaeva, R. I., Benediktova, L. V. (1997). Differentsialnaya diagnostika i korrektsiya narusheniy chteniya i pisma u mladshih shkolnikov. Saint Petersburg: Obrazovanie, 172.

[2] Sadovnikova, I. N. (1995). Narusheniya pismennoy rechi ih preodolenie u mladshih shkolnikov. Moscow: Vlados, 256.

[3] Kornev, A. N. (2006). Osnovyi logopatologii detskogo vozrasta: klinicheskie i psihologicheskie aspektyi. Saint Petersburg: Rech, 380.

[4] Pumfrey, P., Reason, R. (1991). Specific learning difficulties (dyslexia). Windsor: NFER-Nelson, 338. doi: 10.4324/9781315002903

[5] Ho, C. S.-H., Fong, K.-M. (2005). Do Chinese Dyslexic Children Have Difficulties Learning English as a Second Language? Journal of Psycholinguistic Research, 34 (6), 603-618. doi: 10.1007/s10936-005-9166-1

[6] Everatt, J. (1997). The Abilities and Disabilities Associated with Adult Developmental Dyslexia. Journal of Research in Reading, 20 (1), 13-21. doi: 10.1111/1467-9817.00016

[7] Von Suchodoletz, W. (2006). Therapie der Lese-Rechtschreib-Storung (LRS): Traditionelle und alternative Behandlungsmethoden im Uberblick Taschenbuch. Stuttgart: Kohlhammer W., GmbH, 306.

[8] Francoise, E. (2014). Dysorthographie et dysgraphie: 300 exercices: Comprendre, evaluer, remedier, s'entrainer. Issy-les-Moulineaux: Elsevier Masson, XVIII, 182.

[9] Veronique, R., Carine, S. (2008). Ecriture, orthographe dysorthographie. Aix en Provence: PUP, 192.

[10] Levina, R. E. (1963). Vliyanie nedorazvitiya rechi na usvoenie pisma. Spetsialnaya shkola, 1, 62-66.

[11] Cherednichenko, N. V. (2016). Formuvannya fonetiko-grafichnoyi gramotnosti u molodshih shkolyariv iz porushennyam movlennevogo rozvitku v umovah korektsiynogo navchannya. Kyiv: DIA, 212.

[12] Spirova, L. F., Yastrebova, A. V. (1988). Differentsirovannyiy podhod k proyavleniyam narusheniya pisma i chteniya u uchaschihsya obscheobrazovatelnyih shkol. Defektologiya, 5, 372. 
[13] Hvattsev, M. (2003) Aleksiya i disleksiya. Logopediya. Metodicheskoe nasledie. Book IV: Narusheniya pismennoy rechi: Disleksiya. Disgrafiya, 67-111.

[14] Finucci, J. M., Guthrie, J. T., Childs, A. L., Abbey, H., Childs, B. (1976). The genetics of specific reading disability. Annals of Human Genetics, 40 (1), 1-23. doi: 10.1111/j.1469-1809.1976.tb00161.x

[15] McGlannan, F. K. (1968). Familial Characteristics of Genetic Dyslexia. Journal of Learning Disabilities, 1 (3), 185-191. doi: 10.1177/002221946800100303

[16] Roudinesco, M. L., Trela, V., Trela, M. (1950). Etude de quarante cas de dyslexie devolution. Enfance, 1, 31-40. doi: 10.3406/enfan.1950.1160

[17] Gordon, H. W. (1980). Cognitive asymmetry in dyslexic families. Neuropsychologia, 18 (6), 645-656. doi: 10.1016/0028-3932(80)90104-9

[18] Bakwin, H. (1973). Reading Disability in Twins. Developmental Medicine \& Child Neurology, 15 (2), 184-187. doi: 10.1111/j.1469-8749.1973.tb15158.x

[19] Hallgren, B. (1976). Specific dyslexia. Acta Psychiatry Neural., 1950, 65, suppl, 1-287. II Autism. Child. Schizoph., 209-234.

[20] Smith, S., Kimberling, W., Pennington, B., Lubs, H. (1983). Specific reading disability: identification of an inherited form through linkage analysis. Science, 219 (4590), 1345-1347. doi: 10.1126/science. 6828864

[21] Pennington, B. F., Smith, S. D. (1983). Genetic Influences on Learning Disabilities and Speech and Language Disorders. Child Development, 54 (2), 369-387. doi: 10.2307/1129698

[22] Stevenson, J. (1992). Evidence for a genetic etiology in hyperactivity in children. Behavior Genetics, 22 (3), 337-344. doi: 10.1007/bf01066665

[23] Badalyan, L. O. (2000). Nevropatologiya. Moscow: Akademiya, 382.

[24] Zavadenko, N. N. (2003). Narusheniya formirovaniya ustnoy i pismennoy rechi u detey. Vozmozhnosti ih medikamentoznoy korrektsii. Moscow: RKI Sovero press, 64.

[25] Aksenova, N. I., Skvortsova, V. N. (2005). Vzaimosvyaz minimalnoy mozgovoy disfunktsii i disgrafii. Saint Petersburg, 6-7.

[26] Machinskaya, R. I., Lukashevich, I. P., Fishman, M. N. (1997). Dinamika elektricheskoy aktivnosti mozga u detey 5-8 letnego vozrasta v norme i pri trudnostyah obucheniya. Fiziologiya cheloveka, 23, $3-5$.

[27] Farber, D. A., Alferova, V. V. (1972). Elektroentsefalogramma detey i podrostkov. Moscow: Pedagogika, 216.

[28] Fishman, M. N. (2001). Mozgovyie mehanizmyi, obuslavlivayuschie otkloneniya v rechevom razvitii u detey. Defektologiya, 3, 3-9.

[29] Beltyukov, V. I. (1977). Vzaimodeystvie analizatorov v protsesse vospriyatiya i usvoeniya ustnoy rechi (v norme i patologii). Moscow: Pedagogika, 176.

[30] Bekker, R., Sovak, K.-P.; Vlasova, N. A. (Ed.) (1981). Logopediya. Moscow: Meditsina, 288.

[31] Orton, S. (1937). Reading, Writing and speech problems in children. London, 215.

[32] Matejcek, Z. (1987). Dyslexie. Praha: SPN, 236.

[33] Klein, D., Doctor, E. A. L.; Goulandris, N. (Ed.) (2003). Patterns of developmental dyslexia in bilinguals. Dyslexia in different languages: Cross-linguistic comparisons. Philadelphia: Whurr Publishers, 308.

[34] Geva, E., Yaghoub-Zadeh, Z., Schuster, B. (2000). Understanding individual differences in word recognition skills of ESL children. Annals of Dyslexia, 50 (1), 121-154. doi: 10.1007/s11881-000-0020-8

[35] You, H., Gaab, N., Wei, N., Cheng-Lai, A., Wang, Z., Jian, J. et. al. (2011). Neural deficits in second language reading: fMRI evidence from Chinese children with English reading impairment. NeuroImage, 57 (3), 760-770. doi: 10.1016/j.neuroimage.2010.12.003

[36] Ahutina, T. V., Pyilaeva, N. M. (2003). Metodologiya neyropsihologicheskogo soprovozhdeniya detey s neravnomernostyu razvitiya psihicheskih funktsiy. A. R. Luriya i psihologiya XX veka. Moscow: Izdatelstvo «SMYiSL», 181-189.

[37] Novikova, G. R. (2000). Sostoyanie vyisshih psihicheskih funktsiy u detey, postupayuschih v I klass obscheobrazovatelnoy shkolyi (po rezultatam neyropsihologicheskogo issledovaniya). Defektologiya, 2, 51-56.

[38] Alston, J., Taylor, J. (1989). Handwriting Theory. Research and Practice. London, 286.

[39] Bezrukiho, M. M. (1992). Podgotovka k pismu. Moscow: B.i., 91. 